\title{
Natural Reproduction of Kutum Rutilus Kutum (Kamenskii, 1901) in Nesarud and Kazemrud Rivers with Respect of the of Water Quality in the Shale Venture Method
}

\author{
Naderi Jolodar M. , Roohi A., Tahami F., Rowshantabari M., Afraei Bandpaei M. A. \\ Caspian Sea Ecology Research Center, Iranian Fisheries Science Research Institute, Agricultural Research Education and Extension \\ Organization (AREEO), Sari, Iran
}

Email address:

Naderi_j@yahoo.com (Naderi J. M.)

${ }^{*}$ Corresponding author

\section{To cite this article:}

Naderi Jolodar M., Roohi A., Tahami F., Rowshantabari M., Afraei Bandpaei M. A. Natural Reproduction of Kutum Rutilus Kutum (Kamenskii, 1901) in Nesarud and Kazemrud Rivers with Respect of the of Water Quality in the Shale Venture Method. Ecology and Evolutionary Biology. Vol. 2, No. 2, 2017, pp. 21-24. doi: 10.11648/j.eeb.20170202.11

Received: February 17, 2017; Accepted: February 25, 2017; Published: March 21, 2017

\begin{abstract}
The Caspian Kutum Rutilus kutum natural reproduction by shale technique in Nesarud and Kazemrud Rivers (Mazandaran province, Iran) was conducted in March 2017. A total of 353 and 865 spawners of male and female with the sex ratio of 5.1 to 1 were reintroduced to the rivers, respectively. The macrobenthic and fishes were sampled in three stations set downstream and upstream of shale cites monthly. In a review of two rivers, 8,000 macrobenthic were collected belonging to Oligochaeta, Diptera, Ephemeroptera and Trichoptera. Biological indices (EPT and EPT / CHIR ${ }^{\mathrm{i}}$ ) showed the status of water quality in Kazemrud River was better than Nesarud and the water quality declined from upstream to downstream of the rivers. Hilsenhoff biological index (HFBI) showed the Nesarud River water quality was relatively as poor classes quality and in the upstream and downstream of the Kazemrud shale was appropriate. The number of Rutilus kutum larvae hatched in the Nesarud and Kazemrud rivers were 2000000 and 4200000 individuals larvae, respectively and the number of juveniles in the were 1100000 and 1300000 individuals.
\end{abstract}

Keywords: Kazemrud and Nesarud Rivers, Rutilus Kutum, Shale, Natural Reproduction, Caspian Sea

\section{Introduction}

So far with regard to non-native fish there are 53 genera and 79 species belonging to 18 families and 10 orders in the Caspian Sea. Among most residents are belong to fresh water (rivers and wetlands) and about $23 \%$ of them are anadromous [13]. Non-native fish abundance has increased in recent years for the development of fish farming or random along with other cultured species with $17 \%$ in the Caspian fishes due to the construction of Volga-Don Canal. A total of $44 \%$ of Caspian fish has economic exploitation and $24 \%$ are exclusive and are not found in other parts of the world [1]. This species has a special value in terms of providing protection for the special properties of these unique ecosystems and special management should be made to protect them. According to the IUCN, $6 \%$ of the fishes are severely endangered, $6 \%$ endangered, $21 \%$ need of protection and only $36 \%$ in good condition [1]. What ever it can be concluded are the deterioration of habitat, particularly for migratory fish that reproduce in the river and overfishing endangered species of economically important factors [1]. The southern Caspian Sea river to the sea many rivers have special features; first the Alborz mountains near to the sea and the rivers as a result of the short (short distance originates from the estuary) as a result, the reproduction of many species of fish near the place of immigrants from the sea to the river in terms of temperature and substrate of the river.

Unfortunately, in recent years for various reasons such as the development of rice cultivation, multiple dams, reservoirs and diversion, drying rivers, at least in the course of the year have created many obstacles in the path of migrating fish and have been associated with artificial propagation fish releasing [1]. To keep many generations of fish species in the Caspian Sea it seems there is no other option at least to save the ecosystem to favorable use 
of the rivers for the survival and protection of the Caspian ecosystem. For several reasons, including the benefits of natural reproduction of fish, designs and natural reproduction of white fish in the rivers by shale must be done to west Mazandaran investment. In this study, the broodstock spawning of Rutilus kutum in the area surrounded by shale and natural reproduction of the species (the main habitat of reproduction) in the revitalization of the Caspian Sea white fish stocks have a very important role. This study aimed to replicate the performance of investments in shale, macrobenthic and fish in determining water quality in the reproduction of this species were studied in order to assess the natural reproduction of white fish within the shale.

\section{Material and Methods}

Shale cites were established at a distance of about $3 \mathrm{~km}$ of Kazemrud and about $1 \mathrm{~km}$ away of Nesarud estuaries. River shale area was 200 and 150 meters in length in both rivers and 3 stations were determined a range above and below the shale cite. The purpose of the upper shale as Station 1, Station 2 and downstream of shale is the third station. Broodstock spawning was carried out by taking the nearest route for the shale producers to invest in rivers in March 2016. The number of spawners were transferred from the blade bone fishing in the river of Kazemrud to the shale venture was 865 broodstock with the ratio of 1:1.4 male to female and in Nesarud river 353 broodstock with ratio of 1:1.6 male to female, respectively.

Macrobenthic invertebrate was sampled with surber sampler with dimensions of $30.5 \times 30.5 \mathrm{~cm}^{2}$ of $360 \mu$ mesh. Binocular microscope was used for identification keys [15, 17, 19]. To calculate the richness of EPT, the numbers of orders belong to Ephemeroptera, Plecoptera and Trichoptera were measured in each sample and total estimated prevalence of individuals belonging to these three orders. For calculating EPT/CHIR index, total individuals belong to the order of EPT was measured to the frequency of the whole individuals of the family Chironomidae [9]. To evaluate the water quality at each station of the most common biological indicator (HFBI) was used [8], below equation).

$$
H F B I=\frac{\sum\left(x_{i} t_{i}\right)}{n}
$$

Fish inhabit the rivers were caught at the stations up and down of the shale by electro fishing method 7.1 amps $[3,11]$. Shocked fishes were also collected with $6 \mathrm{~mm}$ net [18]. Samples were preserved in $10 \%$ formalin and were transferred to the laboratory for evaluation [3]. To estimate the population of the fish derived from natural reproduction, the plot in any station using net mesh was considered and electro-shocker and net were conducted for population estimate by Lucerne method.

\section{$\mathrm{N}=\mathrm{C} 1^{2} / \mathrm{C} 1-\mathrm{C} 2$}

Statistical analysis was conducted by Systat and two-way ANOVA of variance after normalizing the data using the Kolmogorov-Smirnov method. To compare the means were used Duncan test at 5\% coefficient $(\mathrm{P}=0.05)$ [6].

\section{Results}

A total of 2589 and 1882 fishes were caught in Nesarud and Kazemrud rivers, respectively, that more than $90 \%$ of fish at all stations belonged to Capoeta gracilis. Fish species in Nesarud River were included to Alburnoides eichwldi, pearl fish or gypsies (Alburnus alburnus), Capoeta gracilis, Carassius gibelio, Pseudorasbora parva, carp (Cyprinidae), spiny dogfish stream (Cobitis taenia), stream fishes (Cobitidae), Gasterosteus aculeatus, fishbone (Gasteroteidae), sand goby (Neogobius fluviatilis) of Gobiidaes (Table 1). Whereas the fish of Kazemrud River belonged to Alburnoides eichwldi, Capoeta gracilis, Carassius gibelio, Pseudorasbora parva, spiny dogfish stream (Cobitis taenia), Gasterosteus aculeatus and sand goby (Neogobius fluviatilis). At one time the population was estimated using the method of Lucerne; the number of fish at $100 \mathrm{~m}^{2}$ at the station 1 in Nesarud River was 1613 that more than $85 \%$ were lower than one year of age. The ratio of male to female broodstock of Kutum (taken from bone fish seine shale area) was about $1.5: 1$, respectively which has been reproduced in two rivers (Table 2). The results of this study showed that due to the number of spawners in the Kazemrud River was more than to Nesarud River the numbers of hatched larvae were also higher. But the proportion of larvae and fry compared to the growth rate in Nesarud was more productive and represent more favorable conditions in terms of feeding of the river, water clarity, depth of water, oxygen and other habitat conditions. Bioassay results showed that by increasing the length of Kutum larvae, their weight increased and had allometric growth, so that the sampling in each river in Nesarud and larvae were observed of $120 \mathrm{mg}$ (usually downstream) to about $1 \mathrm{gr}$ weights (within the shale and upstream) (Table 2). During the macrobenthic survey about 8,000 samples of benthic organisms was isolated that more abundance was belonged to Oligochaeta, Diptera, Ephemeroptera and Trichoptera. Oligochaeta was not present in Kazemrud while there was not attend Trichoptera in Nesarud River. In both rivers, the highest frequency was observed in Chironomidae (Diptera) and Ephemeroptera (Baetidae). Genera and families were identified in Nesarud river included Baetis (Baetidae), Heptagenia (Heptageniidae) and the orders Ephemeroptera, Chironomidae, Simuliidae, Tipulidae and Tabanidae of the Diptera, Naididae, Lumbricidae and Tubificidae of Oligochaeta. With the exception of Oligochaeta, Tabanidae and Tipulidae, other benthic invertebrates were also observed in Kazemrud River. In addition, the Kazemrud River Acentralla (Baetidae), Hydropsyche (Hydropsychidae) and Trichoptera were also present. 
Table 1. Relative abundance of fish species caught in the upstream (Station 1) and downstream (Station 3) of shale in Kazemrud and Nesarud Rivers.

\begin{tabular}{|c|c|c|c|c|}
\hline \multirow{2}{*}{$\begin{array}{ll}\text { Species } & \text { Rivers and stations } \\
\end{array}$} & \multicolumn{2}{|c|}{ Nesarud River } & \multicolumn{2}{|c|}{ Kazemrud River } \\
\hline & St: 1 & St: 3 & St: 1 & St: 3 \\
\hline Alburnoides eichwldi & 29 & 3 & 3 & 0 \\
\hline Alburnus alburnus & 21 & 35 & 0 & 0 \\
\hline Capoeta gracilis & 1524 & 870 & 987 & 800 \\
\hline Carassius gibelio & 14 & 8 & 4 & 12 \\
\hline Pseudorasbora parva & 9 & 4 & 0 & 0 \\
\hline Cobitis taenia & 25 & 13 & 13 & 8 \\
\hline Gasterosteus aculeatus & 0 & 9 & 0 & 11 \\
\hline Neogobius fluviatilis & 17 & 8 & 25 & 19 \\
\hline Total & 1639 & 950 & 1032 & 850 \\
\hline
\end{tabular}

Table 2. Number of broodstock, larvae and juveniles fish from reproducing in Kazemrud and Nesarud Rivers.

\begin{tabular}{lll}
\hline Nesarud River & Kazemrud River & Cases investigated \\
215 & 500 & Male spawners \\
138 & 365 & Female spawners \\
$1545.2 \pm 187.5$ & $1462.9 \pm 239.8$ & Females mean \pm sd [ weight $(\mathrm{g})]$ \\
$48.2 \pm 2.4$ & $47.8 \pm 2.7$ & Females mean \pm sd [ length $(\mathrm{cm})]$ \\
2000000 & 4200000 & Number of hatched larvae \\
5666 & 4856 & Average number of larvae hatching in each spawner \\
14493 & 11507 & The average number of larvae hatched per female \\
1100000 & 1300000 & The number of juveniles fish \\
3116 & 1503 & The average number of fry produced by the spawner \\
7971 & 3562 & The average number of fry produced by the female \\
$150-1230$ & $120-1121$ & fry fish weight (mg) (approximately 50-40 days) \\
\hline
\end{tabular}

Biological indices of EPT and EPT/CHIR showed that the status of water quality in Kazemrud was better than Nesarud river but these index values were not significantly different $(\mathrm{P}>0.05)$. Water quality from upstream to downstream of rivers has decreased, which has no significant difference $(\mathrm{P}>0.05)$. Hilsenhoff biological index (HFBI) varied in research stations in Nesarud River from 6.2 to 6.9 shows that water quality is relatively poor and weak classes. The range of HFBI in Kazemrud River changed in the scope of this indicator shows that water quality of upstream and downstream of shale was appropriated. Trend changes in index values of Hydropsychidae $\%$ have been coordinated with other indices. In the present study, based on HFBI index, Nesarud River has been classified relatively weak and poor quality while Kazemrud River was on good water quality. In addition, because of the absence of macrobenthic invertebrate in Kazemrud River in the range of shale, the water quality of this station was not investigated based on biological indicators. According to studies conducted since the river above the production did not potential in terms of live feed (plankton) responsive to the needs of all larvae and fingerlings of this species, therefore, due to competition it seems there is not enough food to grow the larvae of Kutum regularly.

\section{Discussion and Conclusion}

While the Kutum fish migrates into the river next to each female, 3-4 of male fish were observed and in clear water, full of oxygen fishes releasing the eggs and sperm at the same time, the eggs are fertilized and stick to rubble. In the present study, this ratio was observed partially in the river.
Males and females Kutum matured in 2-3 and 3-4 yearsaged, so that males and females in reproduction time weighs at least 400 and $500 \mathrm{~g}$, respectively [4]. In the present study, considering the average length and weight (Table 2), adult males and females reached sexual maturity when released within the shale. Kutum of spring form spawns after crossing the river estuary and entrance to upstream at different distances from the estuary in the gravel and cobblestone [10]. In this study, shale place was like cobblestone and gravel and spawning fish seems to spawning in largely context.

Production of larvae and fingerlings ration to each productive growth rate was higher in Nesarud River (Table 2), indicating more favorable conditions in terms of feeding of the fish, water clarity, depth of water, oxygen and other habitat conditions. This result is based on the estimates of the catches and significant populations of fish species and juveniles residing in rivers $[1,10.3]$. The results of this study showed that most of the fish were caught inhabit the rivers which feed on plankton often in this stage of life, especially of phytoplankton [14]. Because of simultaneously of migration and reproduction of migratory of fish species such as Kutum in the Caspian Sea, food competition could not be ignored with fish inhabit in the studied rivers. Several researchers with the use of EPT and EPT / CHIR index could determine the effects of these activities on the river ecosystem $[12,16,20]$ that the results presented in this study is consistent with other studies. In numerous studies, the HFBI index was used as organic pollution of water for the classification [7, 12, 20]. Macrobenthic distribution primarily influenced by physical and chemical parameters of water such as dissolved oxygen, water temperature, nutrients and habitat function of TDS and pores of rocks, vegetation, depth 
and flow of water. Since the intensity of human activity effect on water quality parameters [2], therefore the distribution of benthic invertebrate influenced and probably due to this factor, the situation in Kazemrud River was somewhat better than Nesarud River.

Accordingly, the results of this study showed that the natural reproduction of Kutum in Nesarud River investment approach more desirable than Kazemrud River in shale, which is probably due to more suitable habitat parameters in the river. As the short length of the downstream selected for this purpose, therefore the Kutum stocks to rebuild of this part of the river spawners should be protected to avoid reducing genetic diversity of this species in their natural reproduction. The method used in rivers that natural reproduction took place in the past history of Kutum. It is also possible to use this method in many species of fish in the Caspian Sea, which even allow artificial reproduction, especially endangered species it is not possible for the Iranian fisheries organization.

\section{References}

[1] Abdoli, A. and Naderi Jolodar, M. 2009. Biodiversity of fishes of the southern Basin of the Caspian Sea. Abzian Scientific Publication, 242p.

[2] Amirkolaie, AK. 2008. Environmental impact of nutrient discharged by aquaculture waste water on the Harazriver. J FishAquat Sci. 3 (5): 275-279.

[3] Bagenal, T. 1978. Methods for assessment of fish production in freshwater. Third edition. Blackwell scientific publication Oxford. London Edinburgh Melbourne. pp. XV+36.

[4] Berg, I. S. 1949. Freshwater fishes of the U. S. S. R. and adjacent countries. Israel program for scientific translation. Jerusalem (1962-1965). 3 Vol.

[5] Buentello, JA., Gatlin, DM., Neill, WH. 2000. Effects of water temperature and dissolved oxygen on daily feed consumption, feed utilization and growth of channel catfish (Ictalurus punctatus). Aquaculture. 182 (3): 339-352.

[6] Conover, W. J., 1980. Practical nonparametric statistics, $2^{\text {nd }}$ edition. Wiley, New York. 219 p.

[7] Entrekin, S., Golladay, S., Ruhlman, M., and Hedman, C., 1999. Unique steephead stream segments in Southwest Georgia: Invertebrate diversity and biomonitoring. The University of Georgia, Athens., Georgia. 4 pp.
[8] Hilsenhoff, W. L., 1988. Rapid field assessment of organic pollution with a family level biotic index J. N. Am. Benthol. Soc. 7: 65-68.

[9] Kerans, G. L., and Karr, J. R., 1994. A benthic index of biotic integrity of rivers of Tennessee Valley. Journal of Applied Ecology. 4: 768-785.

[10] Khanipour, M. 2005. Indentify spot suspicious (Bloom algae) in the southern coastal of Caspian Sea. 10P. Inland Water Aquaculture Research Center. (in Persian).

[11] Ludwig, J., and Reynolds, J. F., 1988. Statistical ecology: a primer on methods and computing. A Niley-Interscience Publication, America. 337 p.

[12] Lydy, M. J., Crawford, C. G., and Frey, J. W., 2000. A comparison of selected diversity, similarity and biotic indices for detecting changes in benthic-invertebrate community structure and stream quality. Arch. Environ. Contom. Toxical. 39: 469-479.

[13] Naderi Jelodar, M. and Abdoli, A. 2004. Atlas of fishes of the southern Caspian Sea (Iranian waters), Iranian Fisheries Journal, 112p (in Persian).

[14] Naderi Jolodar, M., Salarvand, G. R., Abdoli, A., Fazli, H. and Eshaqi Teimori, M. 2014. The feeding strategy of the Caspian Sea Kutum (Rutilus frisii kutum Kamensky, 1901). Aply Ichthyology Journal. pp: 62-75.

[15] Pennak, R. W., 1953. Freshwater invertebrates of the United States. The Ronald Press Company. 769 p.

[16] Pipan, T., 2000. Biological assessment of stream water quality-The example of the Reka River (Slovenia). Karst Research Institute ZRC SAZU, Titov trg 2, Slovenia. 21 p.

[17] Quigley, M., 1986. Invertebrates of streams and rivers. Head of Studies in Environmental Biology. Nene College. Northampton, Edward Arnold. 83 p.

[18] Sheldon, A. L. 1968. Species diversity and longitudinal succession in stream fishes, Ecology Vol. 49. No. 2.

[19] Tachet, H., Richoux, P., Oumaud, M., and Usseglio Polatera, P., 2000. Invertebres d Eau Douce. Systematique, Biologie, Ecologie. CNRS Editions, Paris.275 p.

[20] Voelker, D. C., and Renn, D. E., 2000. Benthic invertebrates and quality of streambed sediments in the White River and selected tributaries in and near Indianapolis, Indiana. USGS Science for a Changing World. $55 \mathrm{pp}$. 